\title{
Study on Value Chain Analysis of Plywood in Western Tamil Nadu, India
}

\author{
P. Balaji ${ }^{*}$, R. Revathi ${ }^{2}$ and V. Karthick ${ }^{1}$ \\ ${ }^{1}$ Directorate of CARDS, TNAU, Coimbatore-3, India \\ ${ }^{2}$ Office of the COE, TNAU, Coimbatore-3, India \\ *Corresponding author
}

\begin{abstract}
A B S T R A C T
Plywood is the type of wood material consists of multiple layers of veneer sheet which are binded together. The present study carried out based on the specific objectives are i) To assess the demand and supply of wood for plywood industry in Coimbatore district, ii) To analyse the value chain of wood in Coimbatore district, iii) To identify the role and interaction among the various stakeholders in value chain. To identify the challenges and opportunities for the stakeholders in the value chain. Since the plywood industries are fragmented across the Coimbatore district, the sample case firm was selected based on the performance and surrounding environment such as Ambiply (Case firm 1), Asian plywood (case firm 2) and Sri ranga plywood(case firm 3). The chief raw materials used by these plywood manufacturing case firms were Eucalyptus, Melia dubia and Dipterocarpus turbinatus. The raw materials were sourced from $250 \mathrm{Kms}$ of surrounding radius from the manufacturing unit. The Forest College and Research Institute has also been playing a vital role in bringing a tie-up between the Plywood Industries across the state and the farmers. In this study, the mapping of value chain and growth rate analysis was done. Challenges and opportunities of stakeholders in value chain were analyzed. The major challenges faced by the farmers were Price fluctuations followed by late return, long rotation and labour intensive production. The major challenges faced by industry are timely procurement of raw materials followed by seasonal variations, lower sales and bad debts. Lack of Raw Materials Supply, power shortage, Lack of Skilled Labour, machine maintenance, etc., are some of the constraints faced by the case firm. This paper also revealed about the demand and supply of raw materials for making plywood.
\end{abstract}

\section{Keywords}

Value chain mapping, Growth rate analysis, Challenges and raw materials

\section{Article Info}

Accepted: 26 April 2020 Available Online: 10 May 2020

\section{Introduction}

The production quantity of plywood in India is estimated at $2537\left({ }^{\circ} 000 \mathrm{~m}^{3}\right)$ in 2018.The production quantity of plywood in world is estimated at $156343.61\left({ }^{\prime} 000 \mathrm{~m}^{3}\right)$ in 2018 (ITTO, 2018). India's contribution in the world level for the production of plywood is
1.62 per cent only. Thus, India had very low share among the world in the production of plywood. Plywood is the type of wood material consists of multiple layers of veneer sheet which are banded together. There is wide opportunity for the plywood manufacturing players in India. Even though India had lowest contribution in the world, its 
major markets were USA, UK, France, Switzerland, Canada and Netherlands. China, USA, Japan, UK, Italy, Germany and France mainly the sawn wood. The plywood demand was increased in domestic market and it had an opportunity for the foreign investors and manufacturers countries who are interested to investing in Indian domestic plywood market (Montiel, 2016). In the case of India, the country has recently experienced a rapid economic growth rate due mainly to economic liberalisation policies that have represented a steadily rising gross domestic product in the country (Ablett, 2007). Other researchers, such as Yadav and Basera (2013), forecasted the Indian forest product at national, regional and global level from 2011 to 2016 and assess the availability, export and import and production of Indian forest products at national, regional and global level. This study revealed the import significance in order to meet domestic production of wood products. On behalf of the Indian Plywood Industries Research and Training Institute IPIRTI, Pandey and Rangaraju (2008) provided an overview of India's wood industry. Their study described the three categories of Indian wood-such as (sawn wood, composite wood panels and pulp wood based) and provided different recommendations to meet the demand of wood as raw material that involve the government, private sector and local institutions as the main key players.

The compound growth rate analysis was given in Table 1 to know the growth rate of plywood. The recent 19 years data which contains export and import quantity along with export and import value was collected for this analysis

From table 1, it could be inferred that both export $(4.45 \%)$ and import quantity $(14.08 \%)$ were increased per year. But import quantity was increased more than the export quantity. Likewise, both export (10.15\%) and import value (19.69\%) were also increased per year. Even though both are increased, import value is more than that of export value. It clarified in graph 1 and it concluded that local demand was increased yearly at highest rate.

The specific objectives of the study includes to assess the demand and supply of wood for plywood industry in Coimbatore district and to analyze the value chain of wood in Coimbatore district and to identify the role and interaction among the various stakeholders in value chain and to identify the challenges and opportunities for the stakeholders in the value chain.

\section{Materials and Methods}

Primary and secondary data were collected in this study. Focus survey method was followed. Ambi plywood (case firm1), Asian plywood (case firm 2) and Sri Ranga plywood (case firm 3) were selected for this study. Compound growth rate was used in order to identify the growth rate. SWOT analysis was done to identify the opportunities, challenges and constraints faced by the case firm. Value chain was mapped with the help of data collected.

The formula for CAGR is:

$\mathrm{CAGR}=(\mathrm{EV} / \mathrm{SV})^{1 / \mathrm{n}}-1$

where:

$\mathrm{EV}=$ Investment's ending value $\mathrm{SV}=$ Investment's starting value $\mathrm{n}=$ Number of investment periods (months, years, etc.).

\section{Results and Discussion}

Demand and supply of raw materials for making plywood, Mapping of value chain which was followed in case firm, Role and Interaction among stakeholders in the firm, 
Sourcing of raw materials, Opportunities and Challenges of Stakeholders in Plywood Value Chain and Constraints faced by the case firms were discussed below.

Table 2 gives the information about demand and supply of raw materials for making plywood by the case firms (Ambi plywood, Asian plywood and sri ranga plywood).

From the above table, it could be inferred that Case firm 1 (Ambi plywood) plays a major role in procurement of raw materials and supply of finished goods followed by case firm 2 (Asian plywood) and case firm 3 (Sri ranga plywood) it also clarified in diagram 1 .

\section{Analysis of value chain Map of Plywood case firm 1}

Mapping the value chain of various woods from procurement to marketing for case firm 1 were given below

\section{Melia dubia}

Farmers-----------> felling groups------> industry----> whole sale->consumers Farmers-----------> felling groups------> industry---->dealers->retailers----> consumers

Farmers----------> felling groups--------> industry---------> consumers (few cases)

\section{Eucalyptus}

Forest department---------> Industry---------$>$ Retailers----------- > consumers

\section{Analysis of value chain map of plywood} case firm 2

Mapping the value chain of various woods from procurement to marketing for case firm 2 were given below

\section{Melia dubia}

Farmers----> merchant----> industry----> retailers----> consumers

\section{Eucalyptus}

Private owners----> industry----> retailers---$>$ consumers

Forest department----> industry----> retailers---> consumers

Private owners----> industry----> industry own outlet----> consumers

\section{Silver oak}

Forest department-------->Industry---------> Retailers-----------> consumers

From the analysis of value chain of both the firms given above, it could be cleared that woods may transferred across various stages of intermediaries and value addition may done in each stage. There is no direct relationship between producer and consumer.

Role and Interaction among the various stakeholders in the value chain

Forest department $\leftrightarrow$ farmers

Tamil Nadu Agricultural university $\leftrightarrow$ farmers

FC\&RI $\leftrightarrow$ farmers

TNAU $\leftrightarrow$ Marketing channel

Agriculture department $\leftrightarrow$ farmers

The technical guidance was requested from forest college and research institute, TNAU, Mettupalayam. FCRI has conceived a comprehensive collaborative research programme coupled with contract tree farming model to promote Meliadubia based plywood farming in Tamil Nadu. Through this model Ambiply has assured a minimum support price of Rs.7500 per ton of wood for the Meliadubia which is first of its kind in the 
country and attracted several farmers. The varieties developed by TNAU for Meliadubia is promoted through this collaboration which attracted many farmers and other stake holders towards tree husbandry.

Table.1 Compound growth rate analysis of plywood

\begin{tabular}{|c|c|c|c|c|}
\hline Year & $\begin{array}{c}\text { Export } \\
\text { quantity } \\
\left(\mathbf{1 0 0 0} \mathbf{~ m}^{\mathbf{3}}\right)\end{array}$ & $\begin{array}{l}\text { Import quantity } \\
\qquad\left(1000 \mathrm{~m}^{3}\right)\end{array}$ & $\begin{array}{l}\text { Export value } \\
\qquad(1000 \$)\end{array}$ & $\begin{array}{l}\text { Import value } \\
\qquad(1000 \$)\end{array}$ \\
\hline 2000 & 23.56 & 28.71 & 7340.78 & 6389.63 \\
\hline 2001 & 29.79 & 42.25 & 4695.22 & 8241.26 \\
\hline 2002 & 43.75 & 15.45 & 8342.65 & 7862.96 \\
\hline 2003 & 14.83 & 16.84 & 9571.34 & 8573.42 \\
\hline 2004 & 28.9 & 18.1 & 18258.58 & 8707.79 \\
\hline 2005 & 32.71 & 15.88 & 20784.24 & 9450.87 \\
\hline 2006 & 41.09 & 31.42 & 25114.15 & 15553.65 \\
\hline 2007 & 106.23 & 57.56 & 28791.66 & 30261.79 \\
\hline 2008 & 70.09 & 90.35 & 26033.56 & 51566.39 \\
\hline 2009 & 66.7 & 82.67 & 16420.44 & 53522.26 \\
\hline 2010 & 57.55 & 169.86 & 27455.27 & 76978.05 \\
\hline 2011 & 49.18 & 200.09 & 18680.21 & 106733.7 \\
\hline 2012 & 55.97 & 128.34 & 25536.77 & 80918.33 \\
\hline 2013 & 32.58 & 115.67 & 22547.78 & 76485.63 \\
\hline 2014 & 97.03 & 121.32 & 56703.02 & 76755.59 \\
\hline 2015 & 63.9 & 113.75 & 34512.55 & 77975.44 \\
\hline 2016 & 75.63 & 118.08 & 52295.22 & 77572.23 \\
\hline 2017 & 51.43 & 141.47 & 35663.82 & 96652.16 \\
\hline 2018 & 31.54 & 151.06 & 31642.29 & 120138.6 \\
\hline CGR(\%) & 4.45 & 14.08 & 10.15 & 19.69 \\
\hline
\end{tabular}

(Source ITTO, 2018)

Table.2 Demand and Supply Raw Material for making plywood by the Case Firms

\begin{tabular}{|l|c|c|c|c|}
\hline Industries & $\begin{array}{c}\text { Procurement of } \\
\text { raw material (in } \\
\text { tonne/month) }\end{array}$ & $\begin{array}{c}\text { Demand of raw } \\
\text { material (in } \\
\text { tonne/month) }\end{array}$ & $\begin{array}{c}\text { Supply of finished } \\
\text { products (in } \\
\text { tonne/month) }\end{array}$ & $\begin{array}{c}\text { Production } \\
\text { capacity (lakh } \\
\text { sq.ft/ annual) }\end{array}$ \\
\hline Case Firm 1 & 600 & 600 & 300 & 5.00 \\
\hline Case Firm 2 & 390 & 405 & 180 & 2.92 \\
\hline Case Firm 3 & 165 & 255 & 90 & 1.67 \\
\hline
\end{tabular}

(Source: Primary data collection from case firms) 
Table.3 Sourcing of raw materials for plywood

\begin{tabular}{|c|c|c|c|c|}
\hline Sourcing place and portfolio & $\begin{array}{c}\text { Meliadubia }^{I} \\
\text { (Malai Vembu) }\end{array}$ & $\begin{array}{c}\text { Eucalyptus }^{2} \\
\text { (Thaila maram) }\end{array}$ & Kurjan $^{3}$ & $\begin{array}{l}\text { Jungle } \\
\text { wood }^{4}\end{array}$ \\
\hline $\begin{array}{l}\text { Erode and Coimbatore } \\
\text { district from mainly from } \\
\text { felling groups/Farmers(Few) }\end{array}$ & $\checkmark$ & & & \\
\hline $\begin{array}{l}\text { Vaalparai, Kodaikkanal and } \\
\text { Kerala Mostly Govt godown } \\
\text { and coffee/ Tea plantation }\end{array}$ & & $\checkmark$ & & \\
\hline $\begin{array}{lr}\text { Kerala/Imported } & \text { from } \\
\text { Foreign countries } & \text { (Direct } \\
\text { import/Traders) } & \end{array}$ & & & $\checkmark$ & \\
\hline Kerala state and Traders & & & & $\sqrt{ }$ \\
\hline
\end{tabular}

Table.4

\begin{tabular}{|l|l|l|}
\hline Stake holders & Opportunities & Challenges \\
\hline Farmer & $\begin{array}{l}\text { Assured price for the produce } \\
\text { Assured supply of quality inputs } \\
\text { Better remunerative price due to absence of middlemen } \\
\text { Timely and free technical guidance } \\
\text { minimum care and management }\end{array}$ & $\begin{array}{l}\text { price fluctuations } \\
\text { Labour intensive production } \\
\text { Long rotation } \\
\text { Late return }\end{array}$ \\
\hline Industry & $\begin{array}{l}\text { Assured quality in the raw material } \\
\text { Protection from market price fluctuations } \\
\text { Enables long term planning } \\
\text { Assured and dedicated supplier base } \\
\text { Uninterrupted and regular supply of raw material }\end{array}$ & $\begin{array}{l}\text { Timely procurement of raw materials } \\
\text { Seasonal variation } \\
\text { Lower primary sales } \\
\text { Bad debts }\end{array}$ \\
\hline Middlemen & $\begin{array}{l}\text { Non perishable good } \\
\text { No investment }\end{array}$ & $\begin{array}{l}\text { Seasonal variation } \\
\text { Bad debts }\end{array}$ \\
\hline
\end{tabular}

Table.5

\begin{tabular}{|l|l|c|}
\hline Sl. No & Constraints faced & Rank \\
\hline $\mathbf{1}$ & Lack of Raw Materials Supply & I \\
\hline $\mathbf{2}$ & Power Shortage & II \\
\hline $\mathbf{3}$ & Lack of Skilled Labour & III \\
\hline $\mathbf{4}$ & Machine maintenance & IV \\
\hline $\mathbf{5}$ & Less plantation of semi hard wood species & V \\
\hline $\mathbf{6}$ & Cutting order problem from forest department & VI \\
\hline $\mathbf{7}$ & Low arrivals in rainy season & VII \\
\hline $\mathbf{8}$ & Lack of labours will results low arrival of wood & VIII \\
\hline $\mathbf{9}$ & Early cutting of trees will results poor arrivals for plywood industry & IX \\
\hline $\mathbf{1 0}$ & Less plantation in the sourcing area & $\mathrm{X}$ \\
\hline
\end{tabular}

(Source: Primary data collection from case firms) 


\section{Fig.1}

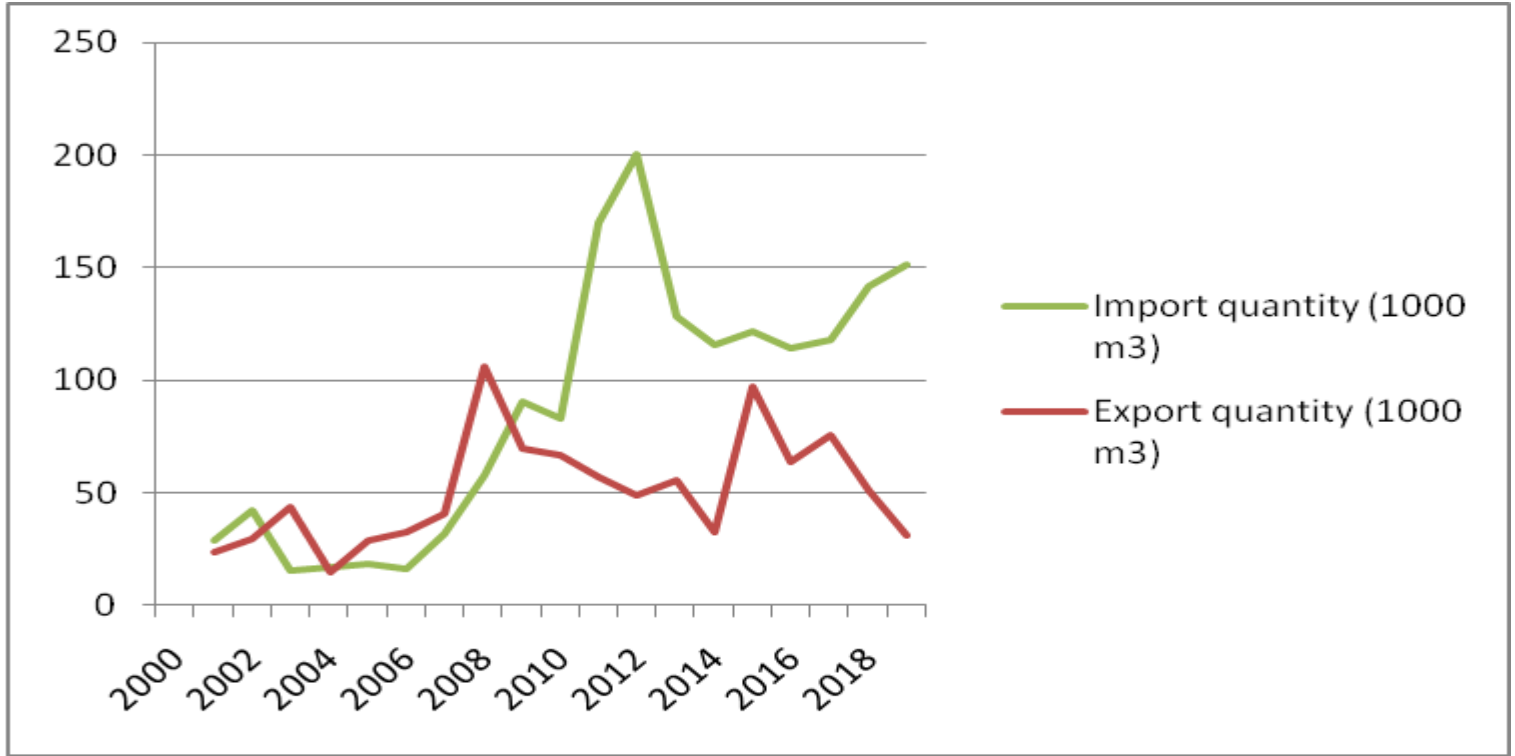

Fig.2

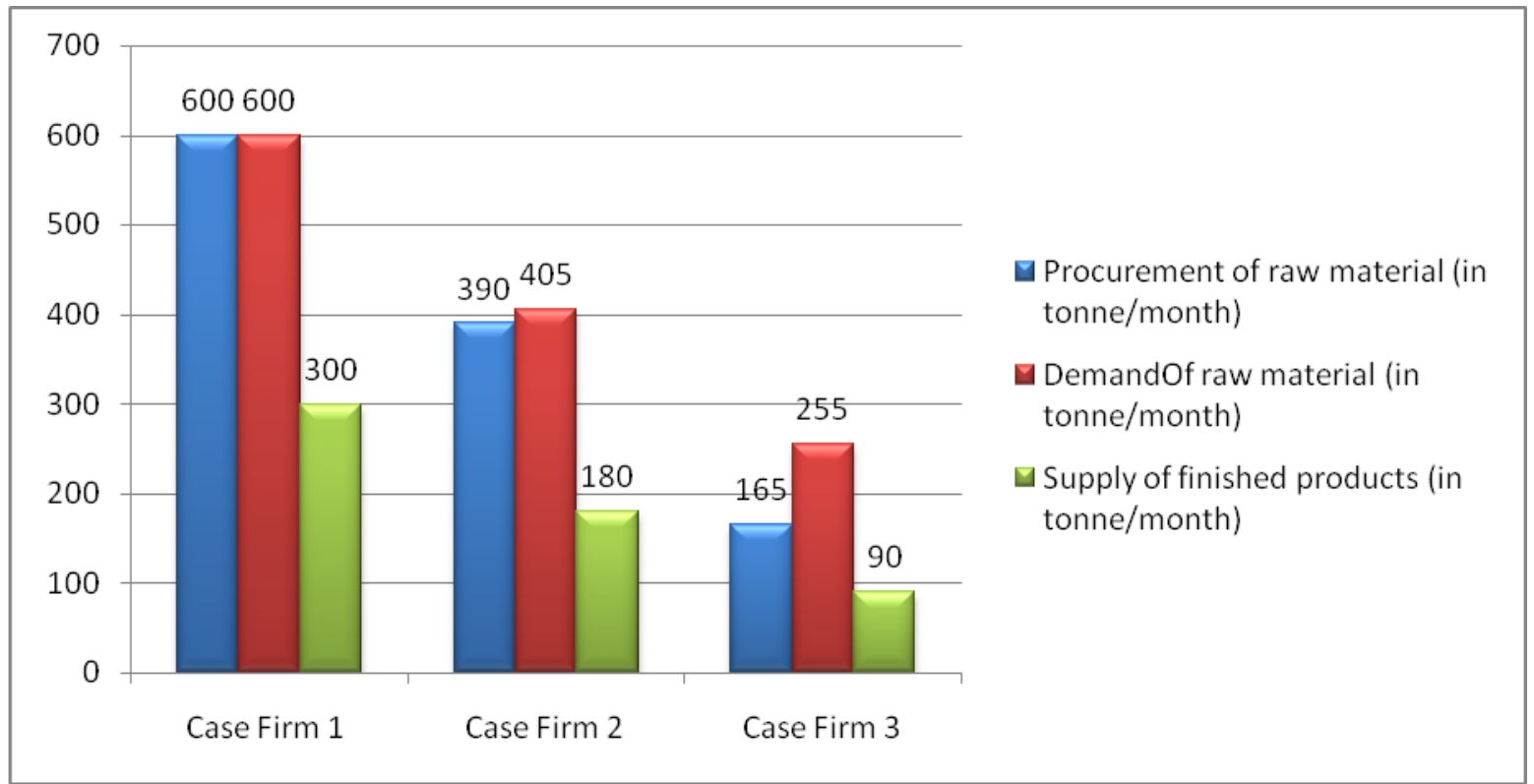

After this association, Ambiply have obtained around $20 \%$ of raw materials directly from the farmers during the last one year. Simultaneously, the industry in association with FCRI to identify alternate plywood species which would be promoted through agro and farm forestry. The institute has conducted research trials for over a decade and promoted the species in a large portion of farm lands

The various sources of raw materials for making plywood are given in the table below

From the above table, it could be cleared that the raw material Melia dubia was procured by 
the case firms from Erode and Coimbatore district, Eucalyptus from Vaalparai, Kodaikkanal and Kerala Mostly Govt godown and coffee/ Tea plantation, Kurjan from Kerala/Imported from Foreign countries (Direct import/Traders) and jungle wood from Kerala state and Traders for making plywood.

Opportunities and challenges for the stakeholders in the plywood value chain

Opportunities and challenges faced by the stakeholders such as Farmer, Industry and Middlemen in the plywood value chain were analyzed below (Table 4).

\section{Constraints faced by the case firms}

Some of the major constraints faced by the case firms during plywood manufacturing process which was collected from primary source are given below (Table 5).

From the table, it could be inferred that case firms faced the major constraints such as lack of raw materials supply followed by power shortage, lack of skilled labour, machine maintenance, less plantation of semi hard wood species, Cutting order problem from forest department, Low arrival in rainy season, Lack of labours will results low arrival of wood, Early cutting of trees will results poor arrivals for plywood industry and Less plantation in the sourcing area.

Conclusion of the study is as follows:

As per compound growth rate analysis, Export (4.45\%) and import quantity (14.08\%) were increased per year. But import quantity was increased more than the export quantity. Likewise, both export (10.15\%) and import value $(19.69 \%)$ were also increased per year. Even though both are increased, import value is more than that of export value. It concluded that local demand was increased yearly at highest rate. Case firm 1 (Ambi plywood) plays a major role in procurement of raw materials and supply of finished goods. There is no direct relationship between producer and consumer. Raw material Melia dubia was procured by the case firms from Erode and Coimbatore district, Eucalyptus from Vaalparai, Kodaikkanal and Kerala Mostly Govt godown and coffee/ Tea plantation, Kurjan from Kerala/Imported from Foreign countries (Direct import/Traders) and jungle wood from Kerala state and Traders for making plywood. The major challenges faced by the farmers were Price fluctuations followed by late return, long rotation and labour intensive production. The major challenges faced by industry are timely procurement of raw materials followed by seasonal variations, lower sales and bad debts. Lack of Raw Materials Supply, power shortage, Lack of Skilled Labour, machine maintenance, etc., are some of the constraints faced by the case firm. From the study, it is cleared that Even though the challenges, opportunities and constraints are more, there is a lot of opportunity for plywood industries in India

\section{References}

Ablett, J., Baijal, A., Beinhocker, E., Bose, A., Farrell, D., Gersch, U., Greenberg, E., Gupta, S. andGupta, S. 2007. The "Bird of Gold": The rise of India's consumer market. San Francisco: McKinsey Global Institute.

Montiel, P. 2016. Analysis of India as a market area for Sawnwood. University of Helsinki, $144 \mathrm{pp}$

Pandey, C.N. and Rangaraju, T.S. 2008. India's industrial wood balance. International Forestry Review 10(2): 173-189.

Yadav, M. and Basera, K. 2013. Status of forest products production and trade. Working Paper Series (2013/1). Centre for Sustainable Forest Management and Forest Certification, Indian Institute of Forest Management, Bhopal 462003, India. .

ITTO, 2018 report 


\section{How to cite this article:}

Balaji, P., R. Revathi and Karthick, V. 2020. Study on Value Chain Analysis of Plywood in Western Tamil Nadu, India. Int.J.Curr.Microbiol.App.Sci. 9(05): 3502-3509. doi: https://doi.org/10.20546/ijcmas.2020.905.416 